南北うねの弧状樹形茶園において 茶株面の東側に凍霜害が集中しやすい原因

\author{
静岡県茶業試験場* \\ 中野敬之** \\ 野菜・茶業試験場 $* * *$ \\ 松尾喜義 \\ (平成10年11月 4 日受理)
}

\title{
Why does Frost Injuries Concentrate on East Side of Canopy Surface on Arc-Shaped Tea (Camellia sinensisL.) Bush Planted with Direction from North to South
}

\author{
Takayuki NAKANO \\ Shizuoka Tea Experiment Station \\ Kiyoshi MATSUO \\ National Research Institute of Vegetable, Ornamental Plants and Tea
}

\begin{abstract}
Summary
In almost cases of past frost disasters for tea (Camellia sinensis L.) field, a partial damage has been observed. Especially, frost injuries used to concentrate only on an east side of the arc-shaped canopy surface for tea bushes planted with the direction from north to south. In this research, the difference of frost tolerance for buds and new shoots between the east and the west side of an arc-shaped canopy surface, effects of freezing temperature and melting method were investigated. Adding analysis of the canopy surface temperature on cold nights, it was observed as follows;

1. Freezing tolerance level of buds and new shoots depended on their growth stage. Their injured and dead rate after the freezing treatment increased as they grew. However, buds and new shoots picked up from the east side of the canopy surface generally showed only a little decline in the freezing tolerance than that from the west side.

2 . On each growing stage, injured and dead rate of tea buds and new shoots were increased at lower temperature and at longer treatment time. They were influenced by the difference of only $1^{\circ} \mathrm{C}$ at a critical temperature.

3. In the past meteological data since 1992 to 1997 at Makinohara AMeDAS, which established in the area of Shizuoka tea experiment station in 1988 by Japanese Meteological Agency, almost freezing night occurred in the atmospheric pressure distribution of which is low at east and high at west around Japanese land. In such a case,

* 个439-0002 菊川町倉沢1706-11

** 現：静岡県中遠農林事務所 T438-8558 磐田市見付3599-4

*** 千439-8501 金谷町金谷2769
\end{abstract}


winds used to breeze from west to east.

4. The leaf temperature of the canopy surface was lower at an opposite side of a wind direction. As most patterns of cold night, the wind from west to east rise the leaf temperature of the west side. In this experiment, the maximum difference was over $2^{\circ} \mathrm{C}$.

It was concluded that the different leaf temperature between east and west and declination of freezing tolerance induce the partial frost injury on the east side of arc-shaped canopy surface.

\section{1 緒}

言

凍霜害は一番茶の安定生産を㤯かす気象災 害で，中山間部の茶産地を中心にこれまでに 多くの被害を及ぼてきたり。栽培現地にお ける被害実態を調查すると, 茶園の立地環境 や新芽の生育ステージ，低温時の気象条件な ど多くの要因によって複雑な被害発生の様相 を呈する傾向があり，茶園内に局部的な被害 がみられることが多い2)。特に，南北方向に定 植された茶園では，写真 1 に示すように茶株 面の東側に被害が集中する傾向がある。

チャ以外の植物を含めた凍霜害の発生メカ ニズムについては，(1)植物の生育ステージや 耐凍性の変動 $3,4,5,6,7,8)$, (2)植物体の凍結や融解

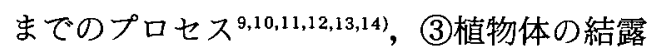
や着霜の有無 ${ }^{15,16,17,18)}$,(4)ほ場の立地条件に伴 う微気象の影響 $2,6,6,8,19,20,21,22,23,24)$, 多方面か らの報告があり，様々な条件が起因している ことが指摘されている。この中で茶株面の東 側に凍霜害が集中しやすい現象については， 東側が低温になりやすく着霜量が多いこ と ${ }^{6)}$, 朝日の直射による急速な融解が細胞を 損傷させること齐，および東側の新芽で耐凍 性が低いこと䇂が一因として指摘されている が, 関連する諸要因を総合的に検討した事例 は少なく断片的な解釈に止まっている。

本研究では，この現象の発生要因を明らか にするため茶株面の位置と茶芽の耐凍性との 関係, 凍結から融解までの諸条件の影響を低 温処理によって調査するとともに，茶園内の 気象観測を併行して行った。得られた結果を 総合的に検討して, 南北うね茶園に扔いて凍 霜害が茶株面の東側に集中しやすい原因につ いて考察した。

\section{2 材料と方法}

2. 1 低温処理による新芽の被害程度の解析 供試材料は茶株面付近に位置する頂・側芽 とし, 茶株面から約 $5 \mathrm{~cm}$ 下の位置で切断して 採取した $10 〜 15$ 本を処理単位とした。試料採 取は午前 $9 \sim 11$ 時に行うように留意した。調 査日の天候や採集に費やした時間の差異がサ ンプルの乾燥程度に及浑す影響を緩和するこ とを目的に，低温処理前にサンプルを数分間 水に浸せきし，その後濡れたままの枝条を 10〜15本でひとまとめにしてアルミ箔に包 み， 3 基のプログラムフリーザー（猘タバイ エスペックSU-220)に入れた。急激な冷却は サンプル内温度の不均一化を招くと考えられ たため, 室温から $0{ }^{\circ} \mathrm{Cまで} 3 \sim 5$ 時間かけて 低下させ, $0^{\circ} \mathrm{C}$ 状態で $5 \sim 8$ 時間維持した。 その後の冷却速度は $-1{ }^{\circ} \mathrm{C} \cdot \mathrm{hr} .^{-1}$ とし, 所定 温度まで䋸やかに冷却した。

低温処理後, $25^{\circ} \mathrm{Cで} 14$ 時間日長に調節した 恒温器内で水道水を入れた容器に水差し状態 で生育させた。被害の調查は新芽の損傷程度 や枯死が明確に区別できる時期を選び, 試験 $1-1$ の萌芽期前では処理の $1 \sim 2$ 週間後に 茶芽が萌芽して新芽になるのを待って行い, 試験 1-2, $1-3$ は処理の $3 \sim 5$ 日後に 行った。被害程度の判定は新芽の組織全てが 黒変したものを枯死芽, 組織の一部でも黒変 したものを損傷芽（枯死芽を含む）とした（写 真 2 参照)。なお, 奇形葉の有無については, 調査員により判断が異なるため被害程度に加 味しなかった。

（1）試験 1-1 萌芽期前における茶株面の 生育場所別, 茶芽の耐凍性検定 静岡県茶業試験場内の1983年に南北方向に 


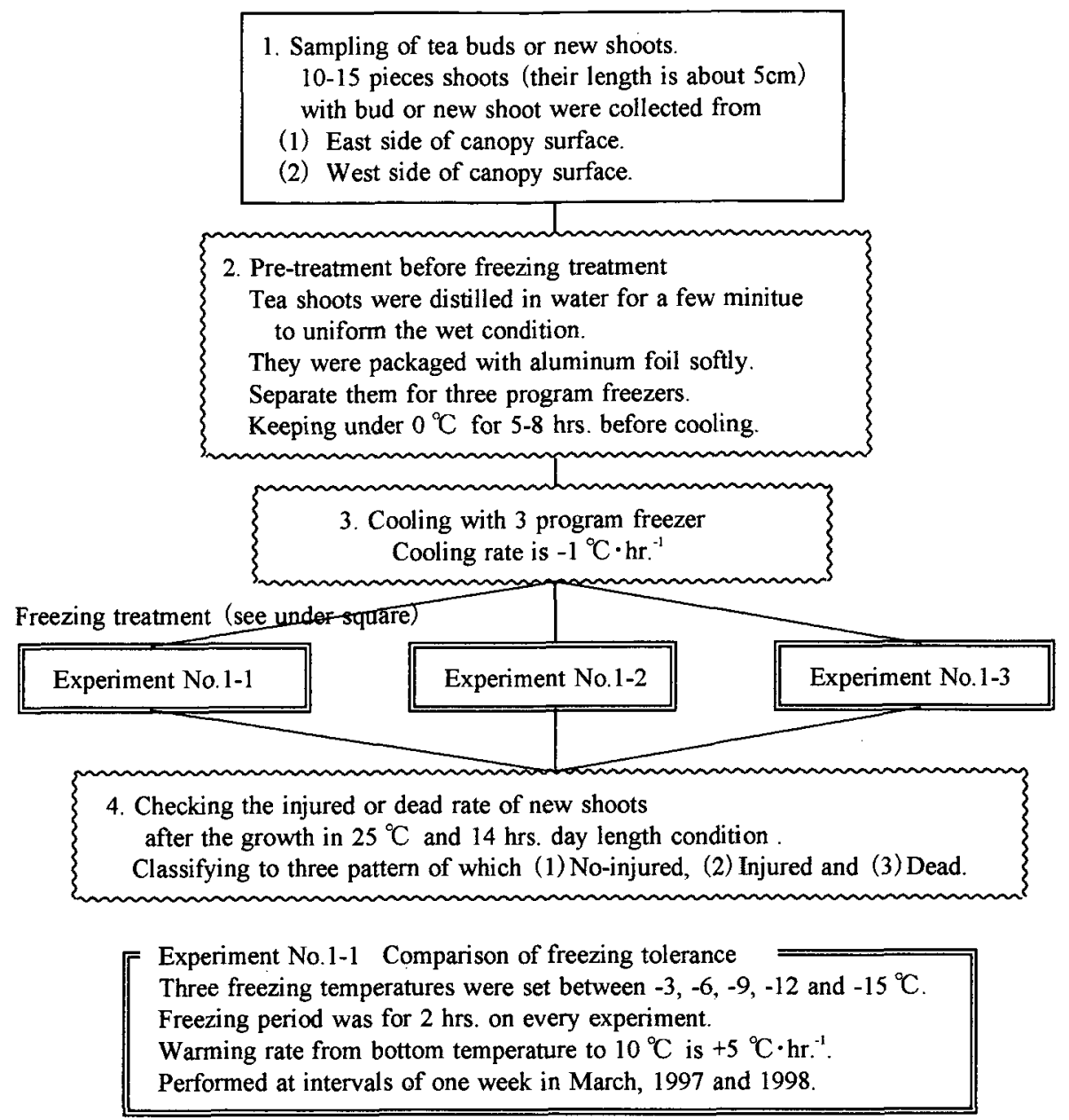

Experiment No.1-2 Comparison of melting rate

Three freezing temperatures were set between $-2,-3,-4$ and $-5{ }^{\circ} \mathrm{C}$.

Freezing period was 2 hours on every experiment.

(1) Slow Dark: Melting to $10^{\circ} \mathrm{C}$ with warming rate of $+2{ }^{\circ} \mathrm{C} \mathrm{hr} .{ }^{-1}$. with program freezer.

(2) Rapid·Dark : Melting under $25{ }^{\circ} \mathrm{C}$ with dark condition for $3 \sim 4$ hrs.

(3) Rapid $\cdot$ Light : Melting with light condition under $5600 \mathrm{~lx}$ at $40 \mathrm{~cm}$ below lk.w. ramp for $20 \sim 30 \mathrm{~min}$.

Performed on early April in 1997 and 1998.

Experiment No.1-3 Comparison of Freezing period

Three freezing temperatures were set on $-2,-3$ and $-4{ }^{\circ} \mathrm{C}$.

Freezing periods were set for 0,2 and $4 \mathrm{hrs}$. on every temperature.

Warming rate from bottom to $10^{\circ} \mathrm{C}$ was $+5{ }^{\circ} \mathrm{C} \cdot \mathrm{hr} .^{-1}$.

Performed on April 15th in 1998.

図 1 低温処理方法の手順と試験構成

Fig. 1 Operational procedure of freezing treatmemt 
定植されだやぶきた’園を供試した。1997年と 1998年の 3 月に約 1 週間間隔で, 茶株面の東 西から枝条を採集して低温処理を行った。季 節と茶芽の生育状況を参考にして, -3 , $-6,-9,-12,-15^{\circ} \mathrm{C}$ において 3 水準の 温度を選び 3 基のプログラムフリーザーを用 いて処理した。所定の温度で 2 時間経過させ

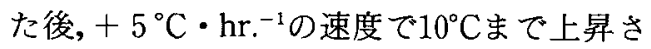
せた。試験規模は 1 区10本とし反復は設けな かった。

（2）試験 1-2 新芽の生育場所, 処理温度 および融解方法の違いによる新芽の被害程 度の検定
静岡県茶業試験場内の1984年に南北方向に 定植されだやぶきた’園を供試した。1997年は 処理温度を- $3,-4,-5{ }^{\circ} \mathrm{C} の 3$ 水準として 4 月 3 日と 7 日に, 1998年は-2,-3, $-4{ }^{\circ} \mathrm{C} て ゙ 4$ 月 1 日，6 日および13日に行った。 達観調査によると，1997年の萌芽期は 4 月 10 日，1998年は 4 月 7 日前後と推察された。

採集からフリーザーによる冷却までの手順 は試験 1-1 と同じである。融解方法は，所 定温度で 2 時間経過させた後, (1)緩速・暗黑 区：そのままフリーザー内で+ $2^{\circ} \mathrm{C} \cdot \mathrm{hr} .^{-1} の$

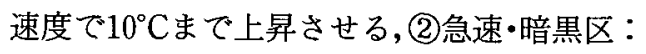
アルミ箔に包んだままのサンプルを $25^{\circ} \mathrm{C}$ 恒

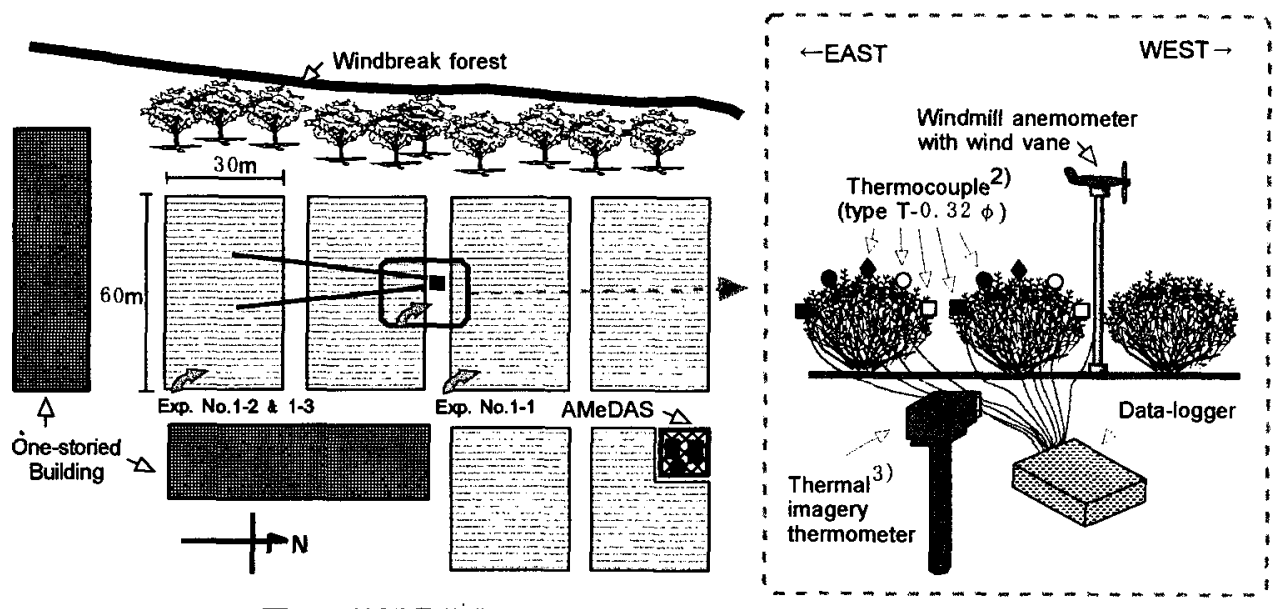

図2 静岡県茶業試験場における茶園微気象の観測状況

Fig. 2 Monitoring profile of micrometeorogical phenomena at the tea field of Shizuoka Tea Experiment Station located at the west edge of Makinohara table land with $34^{\circ} 46.8^{\prime} \mathrm{N}, 138^{\circ} 8.6^{\prime} \mathrm{E}$ and $191 \mathrm{~m}$ above sea level.

1) AMeDAS牧の原観測点は1988年に気象庁が設置した。

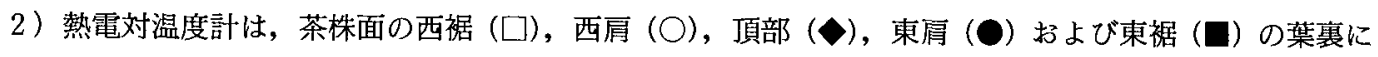
付けた。

3）熱映像温度計（Thermo viewer, JTG6300, JEOL L.T.D.) は, 供試茶園の北側に設置し，レンズを 南へ向けて撮影した。

1) Makinohara point of Automated Meteorogical Data Acquisition System (AMeDAS), which has been measuring air temperature, precipitation, duration of sunshine, wind velocity and direction since 1988, established by Japanese meteorogical agency.

2 ) Thermocouples were set on under surface leaves of the west edge $(\square)$, the west shoulder $(O)$, the top $(\diamond)$, the east shoulder $(\bigcirc)$ and the east edge $(\boldsymbol{\square})$ of arc-shaped bush surface. For these temperature changes on cold night, see fig. 3, 4.

3 ) Thermal imagery thermometer (Thermo viewer, JTG6300, JEOL L.T.D.) was set on the north side of tea field. For these thermal image changes, see plate $3 \sim 12$. 
温器に移して $3 \sim 4$ 時間放置する, (3)急速・ 光区：白熱電球 $(1 \mathrm{kw})$ の $40 \mathrm{~cm}$ 下 $(56001 \mathrm{x})$ に20〜30分置く方法の3つで比較した。なお， (3)では，白熱電球下に数分間放置するだけで サンプルはかなりの熱を帯びたので，絶えず 手で攪抖しながら行った。1997年の試験規模 は 1 区15本で反復無し，1998年は15本で 2 反 復としな。

（3）試験 $1-3$ 新芽の生育場所, 処理温度 および処理時間の違いによる新芽の被害程 度の検定

1998年の4月15日に処理温度を一 2 ， $-3,-4^{\circ} \mathrm{C} て ゙$ 行った。採集ほ場とフリーザー で冷却するまでの手順は試験 1 - 2 と同じで ある。所定温度に到達直後 ( 0 時間)， 2 時間， 4 時間後に試験 $1-2$ の(2)と同じ方法で融解 させた。試験規模は 1 区15本の 2 反復とした。 2 . 2 南北うね弧状樹形茶園の茶株面にお ける葉温分布の調查

1984年に南北方向で定植された後，曲率半 径 $1,100 \mathrm{~mm}$ の可搬型動力摘採・整せん枝機で 管理されている弧状樹形の゙さやまかおり’園 を供試した（図 2 )。

(1) 試験 2-1 熱電対温度計による茶株面 の葉温の測定

1998年の 2 月 5 日に供試園内の隣接した 2 うねについて,それぞれ茶株面の頂部に 1 点, 東，西の両裾部に 2 点，頂部と両裾部の中間 部を東, 西肩部として 2 点の熱電対温度計 (JIS type T, $0.32 \phi)$ をそれぞれの葉裏にセ ロハンテープで接着した。また，隣接した位 置にプロペラ式風向風速計 (㑣英弘精機MA110)を地上 $1.5 \mathrm{~m} の$ 高さに設置した。これらの 観測機器によって 1 分間隔で測定したデータ はデータロガーで10分毎の平均值にまとめ， 計算機を介して記録器に保存した(図 2)。測 定は, 2 月 5 日の夜から 3 月31日の朝まで 行った。

（2）試験 2-2 熱映像温度計による莱株面 の葉温の測定

試験 2-1 で観測中の茶うねについて, 1998年 3 月 24 日の午前 4 時頃から数分間隔で 6 時頃まで, 熱映像温度計（侏）日本電子
JTG6300）を用いて茶園の北側から南に向け ての映像を撮影した（図 2 )。

（3）試験 2-3 牧の原に抢ける低温時の風 向と風速分布

当場内に設置されている牧の原のAMeDAS 観測装置(図2)において, 1992〜1997年の 3 月 中旬から 4 月中旬に 1 時間間隔で収録された 気象データについて, 気温が $3{ }^{\circ} \mathrm{C}$ 以下になっ た時の風向・風速の度数分布を調查した。な お，当装置は1988年に気象庁によって設置さ れたものであり,気温は百葉箱内で測定され， プロペラ式風向風速計は地上 $6 \mathrm{~m} の$ 高さに設 置されている。

\section{3 結果}

3.1 低温処理による新芽の被害程度の解析 （1）試験 I - 1 萌芽期前における茶株面の 生育場所別, 茶芽の耐凍性検定

1997年と1998年の 3 月における茶芽の生育 位置の違いと低温処理による枯死芽率の推移 を表 1 に示した。その結果, 両年とも 3 月上 旬はー $12^{\circ} \mathrm{C}$ 以下の処理でなければ茶芽は枯死 しなかった。しかし，調査日が遅くなり萌芽

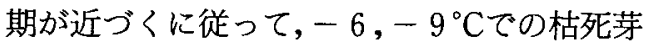
率が増加した。生育位置の違いについては, 1998年 3 月 31 日の $-3^{\circ} \mathrm{C}$ 処理を除くと, 茶株 面の東側から採集した茶芽の枯死芽率は西側 よりも高く推移した。

(2) 試験 1-2 新芽の生育場所, 処理温度 および融解方法の違いによる新芽の被害程 度の検定

1997年の結果を表 2 に，1998年の結果を表 3 亿示した。損傷芽率と枯死芽率の推移をみ ると，これらの高低に最も大きな影響を及ほ す要因は調査日の早晚であり, 調查日が遅い ほどー $2 \sim-3{ }^{\circ} \mathrm{C}$ 比較的高めの温度でも枯 死した（表 2,3 )。

同一調査日内で比較すると，損傷芽率と枯 死芽率に大きな影響を及ほす要因は処理温度 であった。損傷芽率と枯死芽率は処理温度が 低いほど増加するというよりも，むしろ僅か $1{ }^{\circ} \mathrm{C}$ 差により大きく変動する温度帯がみら れた。例えば1998年の 4 月 1 日ではー $3{ }^{\circ} \mathrm{C}$ 
南北うねの弧状樹形茶園において茶株面の東側に凍霜害が集中しやすい原因

\section{表 1 茶株面の東西場所から採取した茶芽における低温処理後の枯死芽率}

Table 1. Changes of dead bud rate by freezing treatment and comparison between sampling position of tea buds.

\begin{tabular}{|c|c|c|c|c|c|c|c|c|c|c|c|c|}
\hline \multirow{2}{*}{$\begin{array}{c}\text { 処理温度 } \\
\text { Freezing } \\
\text { temperature } \\
\left({ }^{\circ} \mathrm{C}\right)\end{array}$} & \multirow{2}{*}{\multicolumn{2}{|c|}{$\begin{array}{l}\text { 採取場所 } \\
\text { Sampling } \\
\text { position of } \\
\text { tea buds }\end{array}$}} & \multicolumn{5}{|c|}{ Mar. in 1997} & \multicolumn{5}{|c|}{ Mar. in 1998} \\
\hline & & & 6 th & 12 th & 18 th & 24 th & 31 st & 4 th & 11th & 18th & 25th & 31st \\
\hline-3 & 東 & East & & & & 0 & 0 & & & & & 20 \\
\hline-3 & & West & & & & 0 & 0 & & & & & 60 \\
\hline-6 & 東 & East & & & 10 & 70 & 100 & & 0 & 10 & 40 & 100 \\
\hline-6 & 西 & West & & & 0 & 0 & 90 & & 0 & 0 & 30 & 100 \\
\hline-9 & 東 & East & $\left.0^{1}\right)$ & 70 & 50 & 90 & 90 & 30 & 0 & 10 & 80 & 100 \\
\hline-9 & & West & 0 & 40 & 0 & 20 & 100 & 0 & 0 & 0 & 50 & 100 \\
\hline-12 & & East & 60 & 100 & 100 & & & 70 & 70 & 90 & 100 & \\
\hline-12 & & West & 0 & 0 & 20 & & & 60 & 10 & 50 & 100 & \\
\hline-15 & 東 & East & 100 & 100 & & & & 100 & & & & \\
\hline-15 & 西 & West & 30 & 90 & & & & 100 & & & & \\
\hline
\end{tabular}

1）表中の数値は低温処理後の枯死芽率（\%) を示す。

1) Means followed by all data are dead bud rate (\%) after freezing tratment.

\section{表 2 採取場所, 低温処理温度および融解方法が茶芽損傷芽率と枯死芽率に及ぼす影響（1997年処理）}

Table 2. Comparison of injured and dead shoot rate after freezing treatment between sampling position, bottom temperature and melting method on the experiment No. 1-2 in 1997.

\begin{tabular}{|c|c|c|c|c|c|c|c|}
\hline \multirow{3}{*}{$\begin{array}{c}\text { A } \\
\text { 採取場所 } \\
\text { Sampling } \\
\text { Position of } \\
\text { new shoots }\end{array}$} & \multirow{3}{*}{$\begin{array}{c}\mathrm{B} \\
\text { 処理温度 } \\
\text { Freezing } \\
\text { temperature } \\
\left({ }^{\circ} \mathrm{C}\right)\end{array}$} & \multirow{2}{*}{\multicolumn{2}{|c|}{$\begin{array}{c}C \\
\text { 融解方法 }\end{array}$}} & \multicolumn{2}{|c|}{ April 3rd } & \multicolumn{2}{|c|}{ April 7th } \\
\hline & & & & 損傷芽率 & 枯死芽率 & 損傷芽率 & 枯死芽率 \\
\hline & & \multicolumn{2}{|c|}{ Melting method } & $\begin{array}{l}\text { Injured } \\
(\%)\end{array}$ & $\begin{array}{l}\text { Dead } \\
(\%)\end{array}$ & $\begin{array}{c}\text { Injured } \\
(\%)\end{array}$ & $\begin{array}{l}\text { Dead } \\
(\%)\end{array}$ \\
\hline 東 East & -3 & 緩速・暗黒 & Slow $\cdot$ Dark & $40^{1)}$ & 10 & 100 & 100 \\
\hline 東 East & -3 & 急速・暗黒 & Rapid $\cdot$ Dark & 60 & 20 & 90 & 40 \\
\hline 東 East & -3 & 緩速 • 光 & Rapid $\cdot$ Light & 60 & 20 & 90 & 80 \\
\hline 東 East & -4 & 緩速・暗黑 & Slow - Dark & 100 & 100 & 100 & 100 . \\
\hline 東 East & -4 & 緩速・暗黒 & Rapid - Dark & 90 & 40 & 100 & 100 \\
\hline 東 East & -4 & 急速 - 光 & Rapid $\cdot$ Light & 100 & 30 & 100 & 100 \\
\hline 東 East & -5 & 緩速・暗黒 & Slow $\cdot$ Dark & 100 & 100 & 100 & 100 \\
\hline 東 East & -5 & 急速・暗黒 & Rapid - Dark & 100 & 70 & 100 & 100 \\
\hline 東 East & -5 & 急速 • 光 & Rapid $\cdot$ Light & 100 & 90 & 100 & 100 \\
\hline 西 West & -3 & 緩速・暗黑 & Slow $\cdot$ Dark & 40 & 10 & 100 & 100 \\
\hline 西 West & -3 & 急速・暗黒 & Rapid - Dark & 30 & 10 & 100 & 100 \\
\hline 西 West & -3 & 緩速・光 & Rapid $\cdot$ Light & 70 & 20 & 100 & 100 \\
\hline 西 West & -4 & 緩速・暗黑 & Slow $\cdot$ Dark & 70 & 50 & 100 & 100 \\
\hline 西 West & -4 & 急速・暗黒 & Rapid - Dark & 90 & 0 & 100 & 100 \\
\hline 西 West & -4 & 急速 · 光 & Rapid $\cdot$ Light & 100 & 70 & 90 & 90 \\
\hline 西 West & -5 & 緩速・暗黒 & Slow $\cdot$ Dark & 100 & 100 & 100 & 100 \\
\hline 西 West & -5 & 急速・暗黒 & Rapid - Dark & 100 & 70 & 100 & 100 \\
\hline 西 West & -5 & 急速 - 光 & Rapid $\cdot$ Light & 100 & 90 & 100 & 100 \\
\hline
\end{tabular}

1 ）表中の数值は低温処理後の損傷死芽率（\%）を示す。

1) Means followed by all data are dead shoot rate (\%) after freezing treatment. 
(茶研報88：9～24，2000)

表 3 採取場所, 低温処理温度および融解方法が茶芽の損傷芽率と枯死芽率に及ぼす影響 (1998年処理)

Table 3. Comparison of injured and dead rate after freezing treatment between sampling position, freezing temperature and melting method on the experiment No. 1.2 in 1998.

\begin{tabular}{|c|c|c|c|c|c|c|c|c|}
\hline \multirow{2}{*}{$\begin{array}{c}\text { A } \\
\text { 採取場所 } \\
\text { Sampling } \\
\text { position of } \\
\text { new shoots }\end{array}$} & \multirow{2}{*}{$\begin{array}{c}\mathrm{B} \\
\text { 処理温度 } \\
\text { Freezing } \\
\text { temperature } \\
\left({ }^{\circ} \mathrm{C}\right)\end{array}$} & \multirow{2}{*}{$\begin{array}{c}\text { C } \\
\text { 融解方法 } \\
\text { Melting } \\
\text { method }\end{array}$} & \multicolumn{2}{|c|}{ April 1st } & \multicolumn{2}{|c|}{ April 6th } & \multicolumn{2}{|c|}{ April 12th } \\
\hline & & & $\begin{array}{l}\text { Injured } \\
(\%)\end{array}$ & $\begin{array}{c}\text { Dead } \\
(\%)\end{array}$ & $\begin{array}{c}\text { Injured } \\
(\%)\end{array}$ & $\begin{array}{c}\text { Dead } \\
(\%)\end{array}$ & $\begin{array}{c}\text { Injured } \\
(\%)\end{array}$ & $\begin{array}{c}\text { Dead } \\
(\%)\end{array}$ \\
\hline East & -2 & Slow $\cdot$ Dark & $3^{\text {1)a2) }}$ & $0^{\mathrm{a}}$ & $10^{\mathrm{a}}$ & $0^{\mathrm{a}}$ & $100^{\mathrm{a}}$ & $90^{\mathrm{a}}$ \\
\hline East & -2 & Rapid • Dark & $0^{\mathrm{a}}$ & $0^{\mathrm{a}}$ & $13^{\mathrm{ab}}$ & $0^{\mathrm{a}}$ & $87^{\mathrm{a}}$ & $70^{\mathrm{a}}$ \\
\hline East & -2 & Rapid $\cdot$ Light & $0^{\mathrm{a}}$ & $0^{\mathrm{a}}$ & $20^{\mathrm{abc}}$ & $0^{\mathrm{a}}$ & $83^{\mathrm{a}}$ & $63^{\mathrm{a}}$ \\
\hline East & -3 & Slow - Dark & $0^{\mathrm{a}}$ & $0^{\mathrm{a}}$ & $60^{\text {ad }}$ & $13^{\mathrm{ab}}$ & $100^{\mathrm{a}}$ & $100^{\mathrm{a}}$ \\
\hline East & -3 & Rapid $\cdot$ Dark & $0^{\mathrm{a}}$ & $0^{\mathrm{a}}$ & $70^{\mathrm{ac}}$ & $10^{\mathrm{ab}}$ & $100^{\mathrm{a}}$ & $97^{\mathrm{a}}$ \\
\hline East & -3 & Rapid - Light & $0^{\mathrm{a}}$ & $0^{\mathrm{a}}$ & $77^{\text {bd }}$ & $47^{\circ}$ & $100^{\mathrm{a}}$ & $93^{\mathrm{a}}$ \\
\hline East & -4 & Slow - Dark & $90^{\mathrm{b}}$ & $70^{\mathrm{b}}$ & $100^{d}$ & $97^{\mathrm{c}}$ & $100^{\mathrm{a}}$ & $100^{\mathrm{a}}$ \\
\hline East & -4 & Rapid - Dark & $83^{\mathrm{b}}$ & $60^{\mathrm{b}}$ & $100^{\mathrm{d}}$ & $00^{c}$ & $100^{\mathrm{a}}$ & $100^{\mathrm{a}}$ \\
\hline East & -4 & Rapid • Light & $73^{\mathrm{b}}$ & $50^{\mathrm{b}}$ & $100^{\mathrm{d}}$ & $00^{c}$ & $100^{\mathrm{a}}$ & $100^{\mathrm{a}}$ \\
\hline West & -2 & Slow · Dark & $0^{\mathrm{a}}$ & $0^{\mathrm{a}}$ & $3^{\mathrm{a}}$ & $0^{\mathrm{a}}$ & $100^{\mathrm{a}}$ & $87^{\mathrm{a}}$ \\
\hline West & -2 & Rapid · Dark & $3^{\mathrm{a}}$ & $0^{\mathrm{a}}$ & $7^{\mathrm{a}}$ & $3^{\mathrm{a}}$ & $100^{\mathrm{a}}$ & $93^{\mathrm{a}}$ \\
\hline West & -2 & Rapid - Light & $0^{\mathrm{a}}$ & $0^{\mathrm{a}}$ & $13^{\mathrm{ab}}$ & $0^{\mathrm{a}}$ & $20^{\mathrm{b}}$ & $7^{\mathrm{b}}$ \\
\hline West & -3 & Slow - Dark & $3^{\mathrm{a}}$ & $0^{\mathrm{a}}$ & $77^{\text {bd }}$ & $50^{\mathrm{b}}$ & $100^{\mathrm{a}}$ & $97^{\mathrm{a}}$ \\
\hline West & -3 & Rapid $\cdot$ Dark & $0^{\mathrm{a}}$ & $0^{\mathrm{a}}$ & $47^{\mathrm{ab}}$ & $13^{\mathrm{ab}}$ & $100^{\mathrm{a}}$ & $97^{\mathrm{a}}$ \\
\hline West & -3 & Rapid - Light & $7^{\mathrm{a}}$ & $0^{\mathrm{a}}$ & $60^{\mathrm{ab}}$ & $27^{\mathrm{ab}}$ & $83^{\mathrm{a}}$ & $60^{\mathrm{a}}$ \\
\hline West & -4 & Slow - Dark & $70^{\mathrm{b}}$ & $57^{\mathrm{b}}$ & $100^{b}$ & $00^{c}$ & $100^{\mathrm{a}}$ & $100^{\mathrm{a}}$ \\
\hline West & -4 & Rapid - Dark & $67^{\mathrm{b}}$ & $43^{\mathrm{b}}$ & $100^{\mathrm{d}}$ & $97^{\mathrm{c}}$ & $100^{\mathrm{a}}$ & $100^{\mathrm{a}}$ \\
\hline West & -4 & Rapid - Light & $67^{\mathrm{b}}$ & $50^{\mathrm{b}}$ & $100^{\mathrm{d}}$ & $97^{c}$ & $100^{\mathrm{a}}$ & $100^{\mathrm{a}}$ \\
\hline 効果の & Sampling & position A & *3) & NS & NS & NS & $* *$ & $* *$ \\
\hline 有意性の & Freezing te & nperature $\mathrm{B}$ & $* * *$ & $* * *$ & $* * *$ & $* * *$ & $* * *$ & $* * *$ \\
\hline Effest & Melting & iethod C & NS & NS & NS & NS & $* * *$ & $* * *$ \\
\hline & & $\times \mathrm{B}$ & $* * *$ & NS & NS & NS & $*$ & NS \\
\hline & & $\times \mathrm{C}$ & NS & NS & NS & $* *$ & $* * *$ & $* * *$ \\
\hline & & $\times \mathrm{C}$ & NS & NS & NS & $*$ & $* * *$ & $* * *$ \\
\hline & $\mathrm{A} \times$ & $\mathrm{B} \times \mathrm{C}$ & NS & NS & NS & * & $* * *$ & $* *$ \\
\hline
\end{tabular}

1 ）表中の数值は, 15 本の新芽を低温処理した後の損傷芽率と枯死芽率で, 2 反復の平均值である。

2) 同一の英小文字を付した区間に有意差がないことを示す (Tukey $5 \%$ )。

$3)^{*}, * *$ ***は，それぞれ危険率10，5，1\%有意差が認められたことを示す。

1) Means are average of which 15 pieces of new shoots are treated with repeated twice.

2) Means followed by the same letters are not significantly different at $5 \%$ level according to Tukey's multiple range test.

$3)^{*},{ }^{* *}$ and ${ }^{* * *}$ denote that the significance levels are less than 10,5 and $1 \%$, respectively.

とー4 ${ }^{\circ} \mathrm{C}$ 処理間で, 4 月 6 日ではー $2{ }^{\circ} \mathrm{Cと一}$ $3{ }^{\circ} \mathrm{C}$ 処理間で極端な差が認められた（表 3 )。 新芽の生育位置や融解方法については両年と も明らかな差はみられなかった。しかし,1998 年の 4 月 13 日の $-2{ }^{\circ} \mathrm{C}$ 処理では西側から採集 した新芽について電球で急速に融解した場合
のみ，枯死芽率と損傷芽率が極めて小さかっ た（表 3 )。

（3）試験 $1-3$ 新芽の生育場所, 処理温度 および処理時間の違いによる新芽の被害程度 の検定

$-2,-3,-4^{\circ} \mathrm{C}$ 到達直後にサンプルを 
融解させた場合 ( 0 時間)，2 時間および 4 時 (表 4 , 写真 2 )。

間処理した場合に扔ける影響を表 4 に示し た。その結果, $-4{ }^{\circ} \mathrm{Cでは} 0$ 時間でもほとんど

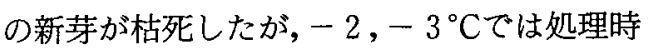
間が長いほど損傷芽率と枯死芽率が増加した

\section{表 4 採取場所, 低温処理温度と時間が茶芽の損傷率と枯死率に及ほす影響}

Table 4. Comparison of injured and dead shoot rate after freezing treatment between sampling position, freezing temperature and duration on the experiment No. 1-3 in 1998.

\begin{tabular}{|c|c|c|c|c|}
\hline $\begin{array}{c}\text { A } \\
\text { 採取場所 } \\
\text { Sampling } \\
\text { position of } \\
\text { new shoots }\end{array}$ & $\begin{array}{c}\text { B } \\
\text { 処理温度 } \\
\text { Freezing } \\
\text { temperature } \\
\left({ }^{\circ} \mathrm{C}\right)\end{array}$ & $\begin{array}{c}\text { C } \\
\text { 処理時間 } \\
\text { Freezing } \\
\text { duration } \\
\text { hrs. } \\
\end{array}$ & $\begin{array}{c}\text { 損傷芽率 } \\
\text { Injured } \\
(\%)\end{array}$ & $\begin{array}{c}\text { 枯死芽率 } \\
\text { Desd } \\
\text { (\%) }\end{array}$ \\
\hline 東 East & -2 & 0 & $0^{1) \mathrm{a} 2)}$ & $0^{\mathrm{a}}$ \\
\hline 東 East & -2 & 2 & $77^{\mathrm{b}}$ & $10^{\mathrm{a}}$ \\
\hline 東 East & -2 & 4 & $100^{\mathrm{b}}$ & $77^{b c}$ \\
\hline 東 East & -3 & 0 & $13^{\mathrm{a}}$ & $0^{\mathrm{a}}$ \\
\hline 東 East & -3 & 2 & $100^{\mathrm{b}}$ & $90^{\mathrm{bc}}$ \\
\hline 東 East & -3 & 4 & $100^{\mathrm{b}}$ & $100^{\mathrm{c}}$ \\
\hline 東 East & -4 & 0 & $100^{\mathrm{b}}$ & $100^{c}$ \\
\hline 東 East & -4 & 2 & $100^{\mathrm{b}}$ & $100^{\mathrm{c}}$ \\
\hline 東 East & -4 & 4 & $100^{\mathrm{b}}$ & $100^{\mathrm{c}}$ \\
\hline 西 West & -2 & 0 & $47^{\mathrm{b}}$ & $3^{\mathrm{a}}$ \\
\hline 西 West & -2 & 2 & $93^{\mathrm{b}}$ & $40^{\mathrm{ab}}$ \\
\hline 西 West & -2 & 4 & $100^{b}$ & $90^{c}$ \\
\hline 西 West & -3 & 0 & $57^{\mathrm{b}}$ & $0^{\mathrm{a}}$ \\
\hline 西 West & -3 & 2 & $100^{\mathrm{b}}$ & $70^{\mathrm{bc}}$ \\
\hline 西 West & -3 & 4 & $100^{b}$ & $100^{\mathrm{c}}$ \\
\hline 西 West & -4 & 0 & $93^{b}$ & $73^{\mathrm{bc}}$ \\
\hline 西 West & -4 & 2 & $100^{\mathrm{b}}$ & $100^{c}$ \\
\hline 西 West & -4 & 4 & $100^{\mathrm{b}}$ & $100^{c}$ \\
\hline 効果の 採取場所 & Sampling position & $A$ & NS & NS \\
\hline 有意性 処理温度 & Freezing temperature & B & $* * * 3)$ & $* * *$ \\
\hline \multirow[t]{5}{*}{ Effest 処理時間 } & Freezing duration & $\mathrm{C}$ & $* * *$ & $* * *$ \\
\hline & $A \times B$ & & $* * *$ & $*$ \\
\hline & $A \times C$ & & NS & NS \\
\hline & $\mathrm{B} \times \mathrm{C}$ & & $* *$ & $* * *$ \\
\hline & $\mathrm{A} \times \mathrm{B} \times \mathrm{C}$ & & NS & NS \\
\hline
\end{tabular}

1 ) 表中の数値は, 15本の新芽を低温処理した後の損傷芽率と枯死芽率で, 2 反復の平均值である。

2 ）同一の英小文字を付した区間に有意差がないことを示す (Tukey $5 \%$ )。

3)*＊*，**は，それぞれ危険率10，5，1\%で有意差が認められたことを示す。

1) Means are average of which 15 pieces of new shoots are treated with repeated twice.

2) Means followed by the same letters are not significantly different at $5 \%$ level according to Tukey's multiple range test.

$3)^{*}, * *$ and *** denote that the significance levels are less than 10,5 and $1 \%$, respectively. 

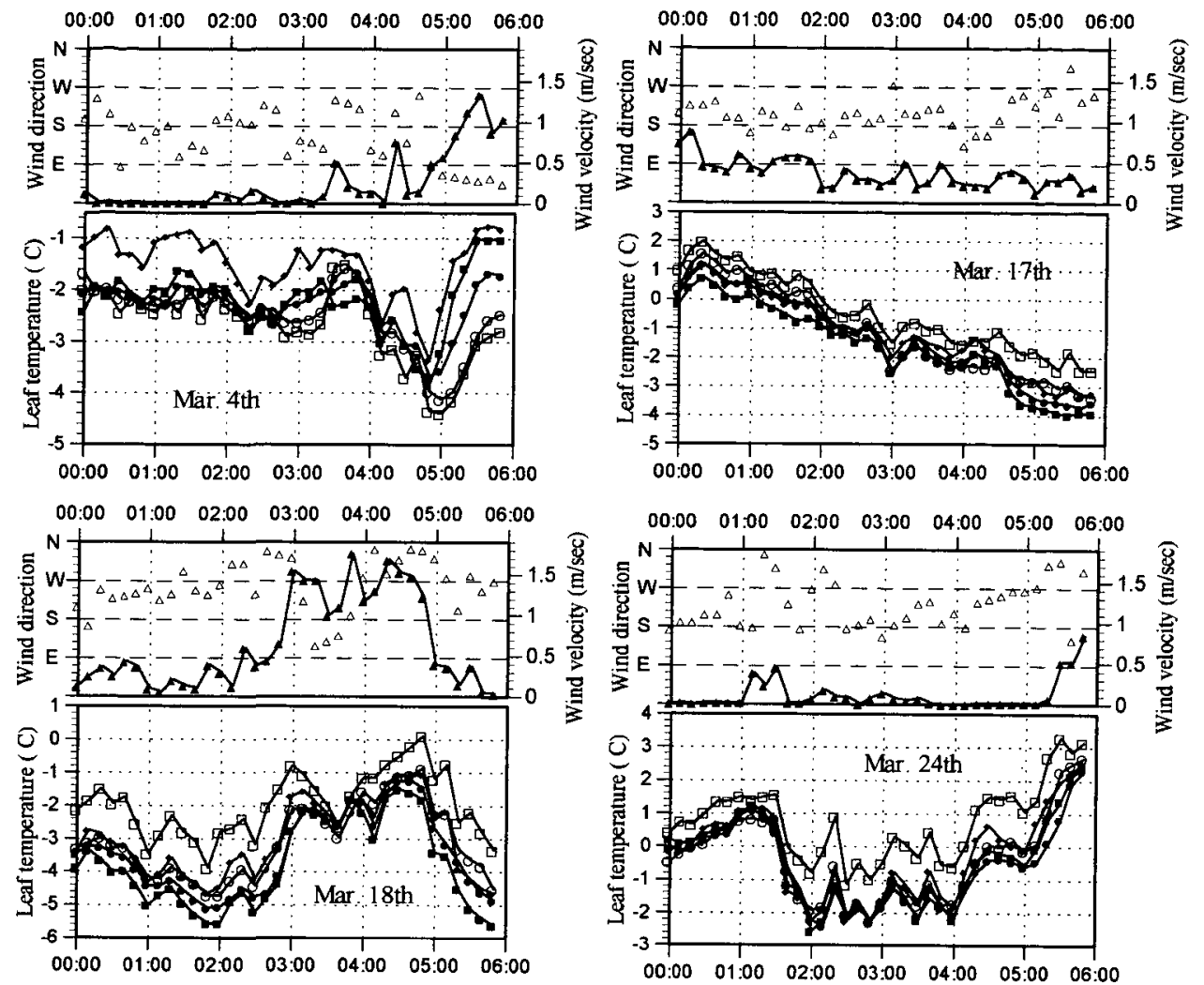

図 3 低温時における風向, 風速, および茶株面の葉温の推移

Fig. 3 Changes of wind direction, wind velocity and leaf temperatuers of canopy surface at cold night in 1998.

1) 図中の記号はそれぞれ，風向 $(\triangle)$ ，風速 $(\Delta)$ ，と茶株面の西裾 $(\bigcirc)$, 西肩 $(\square)$, 頂部 $(\bullet)$, 東肩 $(\boldsymbol{\square})$, および東裾（○）の葉温を示す。

1) Wind direction $(\triangle)$, wind velocity $(\Delta)$, leaf temperature of the west edge $(O)$, the west shoulder $(\square)$, the top $(\boldsymbol{)})$, the east shoulder $(\boldsymbol{\square})$ and the east edge $(\boldsymbol{O})$.

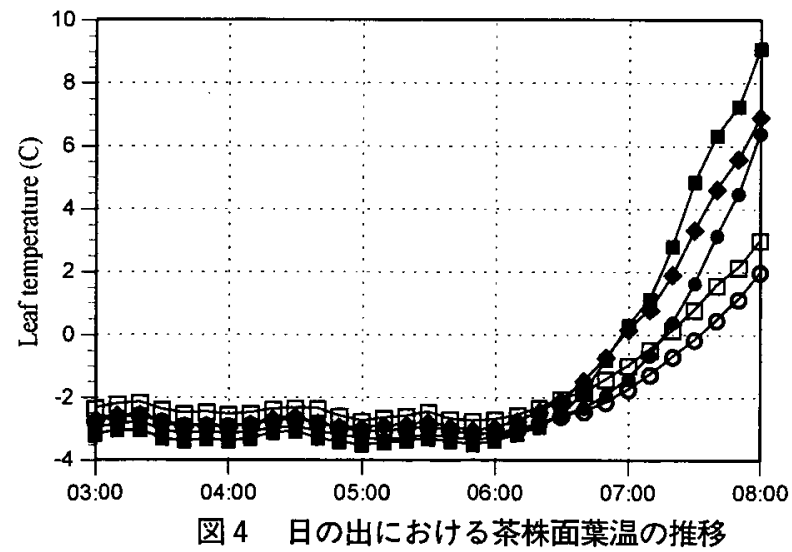

Fig. 4 Changes of leaf temperatures of canopy surface around daybreak time.

1）観測期間中に気温が水点下になった19日間の平均值をまとめた。

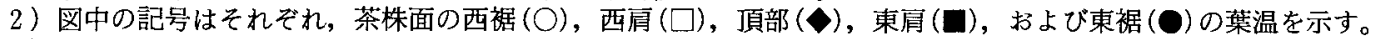

1) Leaf temperature mean average value of 19 frost days in experiment period.

2) Leaf temperature of the west edge $(\bigcirc)$, the west shoulder $(\square)$, the top $(\bullet)$, the east shoulder $(\square)$ and the east edge $(\mathbf{O})$. 
2.2 南北うね弧状樹形茶園の茶株面にお ける葉温分布の調查

（1）試験 2-1 熱電対温度計による茶株面 の葉温の測定

1998年の 2 月 6 日から 3 月31日までの調査 期間において茶株面の葉温が氷点下を記録し たのは19日間であった。代表的な例として，

3 月 $4 ， 17 ， 18 ， 24$ 日の結果を図 3 に示した。 茶株面が氷点下を記録する場合はほとんどが 西高東低の気压配置で, その時の供試園内の 風向は西〜南で微風条件が多かった。茶株面 の葉温は西肩で最高值を，東扇で最低値を示 すことが多く，ほとんどの場合両者間に $1^{\circ} \mathrm{C}$ 以上の差が認められ，特に 3 月 17 日の午前 5 時頃や 3 月 18 日の午前 $0 \sim 3$ 時では $2{ }^{\circ} \mathrm{C}$ 以上
の差が認められた(図 3 )。この現象が風向と 密接に関係していることを示唆する具体例と して，3月18日があげられる。この日は，午 前 $3 \sim 4$ 時に風向が南に変わったが，この時 間帯は茶株面の葉温は，東西間で差がなく なった（図 3)。

低温になった19日間について部位別に葉温 の平均值を求め，その推移を図 4 に示した。 これをみると，日の出に伴う葉温の上昇は午 前 6 時半頃からと推定される。それ以後の葉 温の上昇量は, 東肩, 頂部, 東裾, 西肩, 西 裙の順序で多く，午前 6 時半から 8 時までの 葉温の上昇速度は東肩で $+0.13^{\circ} \mathrm{C} \cdot \mathrm{min}^{-1}$, 西 肩で+0.07 $\mathrm{C} ・ \min .^{-1}$ であった。

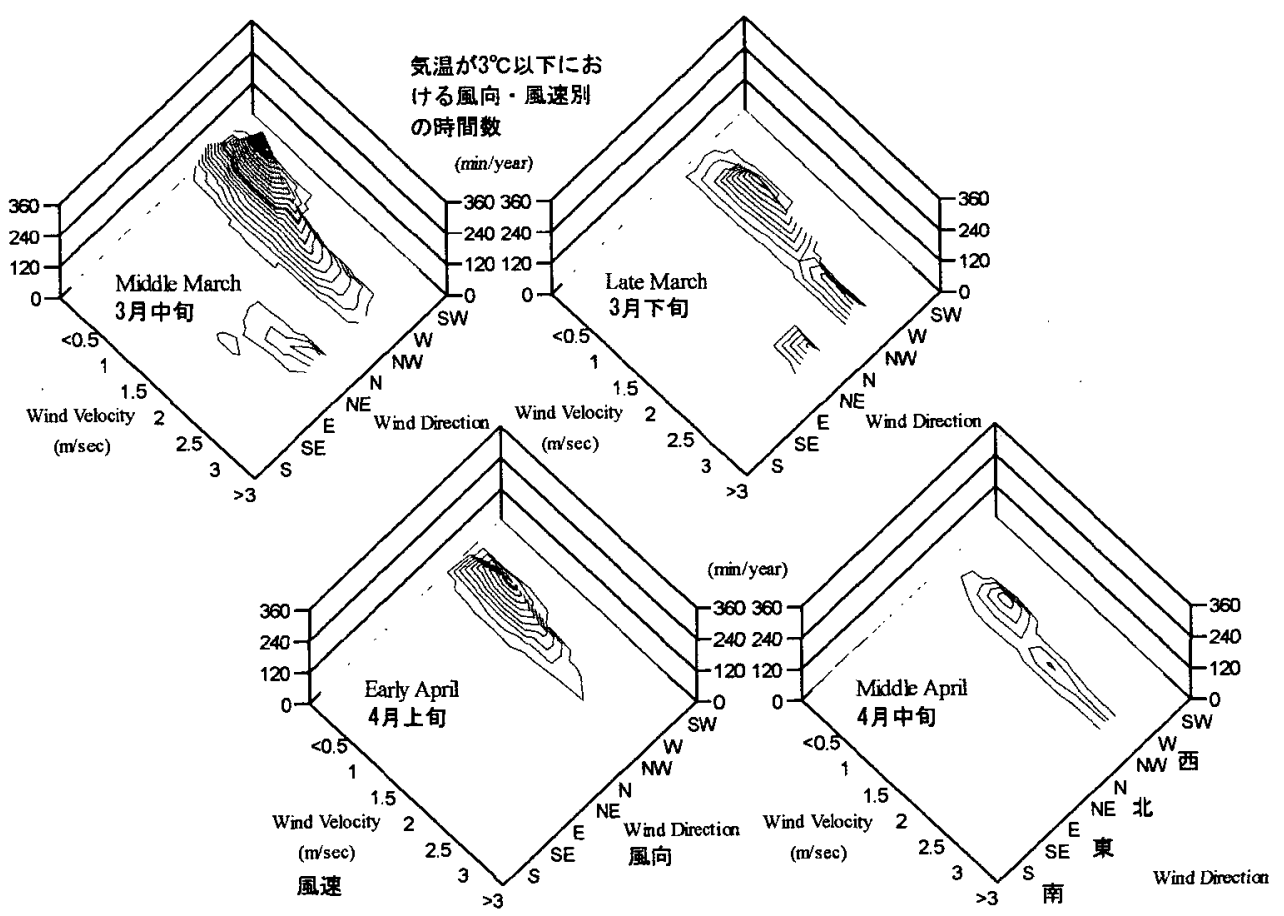

図 5 牧の原AMeDAS観測点における気温が $3^{\circ} \mathrm{C}$ 以下での風向風速の度数分布（1992 1997年の集計値）

Fig. 5 Frequency distribution (mim./year) of wind direction and velocity below $3^{\circ} \mathrm{C}$ of air temperatue.

1）1992 1997年の 3 月中旬（左上，３月下旬（右上）４月上旬（左下）扔よび 4 月中旬（右下）にお いて，1時間間隔で記録された風向, 風速データについて気温が $3^{\circ} \mathrm{C}$ 以下時間数を集計して 1 年当た りの平均值を求めた。

1) Data was calculated since 1992 to 1997 at areal observation system of Makinohara AMeDAS. 
（2）試験 $2-2$ 熱映像温度計による茶株面 の葉温の観測

3 月24日に実施した熱映像温度計の撮影結 果を写真 3〜10に示した。3月24日も西高東 低の気圧配置で西からの微風条件であった

(図 3 )。茶株面の葉温は頂部を境に西側と東 側で大きく異なり，ほとんどの場合東側が低 く推移した(写真 $3 \sim 10) 。$ 試験 $2-2$ では10 分毎の平均値を収録したので，図 3 ではほぼ 一定の風向で推移しているようにみえるが, 実際に茶園に立って風向風速計を観察する と, 普段は西からの微風であっても瞬時的に 南風や東風が吹くことがあり，その度に茶株 面温度の分布は写真 8,9 のように東西間の 差がなくなった。

（3）試験 $2-3$ 牧の原における低温時の風 向と風速分布

当場内に設置されている牧の原台地の AMeDAS（図 2) による1992～1997年の観測 值を集計し，気温が $3{ }^{\circ} \mathrm{C}$ 以下になった時間帯 に抢ける風向風速の分布を調査した。その結 果, 3 月中下旬は一部で北〜東の強風がみら れたが，4月にはなくなった。調査期間を通 してみると, 低温時は西からの微風条件が最 も多かった（図 5 )。

\section{4 考察}

南北うね茶園において茶株面の東側で涷霜 害が集中しやすい原因についてはこれまでに 結論が明確にされていないことから, 栽培現 地では様々な説明がなされているようであ る。特に, 生産者や指導者の間では, 朝日の 直射による急速な融解を主因とする説が支持 されている。しかし，チャ以外の植物を含め た過去の研究を参照すると, 朝日説を証明す る根拠は乏しく，むしろ，これに懐疑的な結 果を示した報告が多い。

淵之上"9は，チャ新芽の低温処理試験にお いて，急速な融解が被害率を有意に高めた結 果をもとに朝日の直射による影響を一因とし て指摘した。しかし，原田・中山 ${ }^{10)}$ は同様な結 果を得ながらも急速融解の影響が軽微である ことを重視し, 朝日説に対して懐疑的な考察
をしている。一方, 高橋ら ${ }^{61}$ は, 春先の低温時 は西からの微風条件が多いことと茶株面が風 向の反対側で最低温度を示す現象を見出した が，この結果が朝日説を否定する材料になら ないと言及している。

チャ以外の植物における同様な現象につい ては，代表例として山の南東部斜面で多発す る樹木の凍霜害に関する一連の研究があげら れる。今田・武藤 ${ }^{11}$ は, 低温処理後のトドマツ を值射日光下に置くと被害が顕著になったこ とから，朝日の直射による急激な融解が原因 と結論づけた。吉田・酒井 ${ }^{13,14)}$ は, ツゲとイヌ ツゲを供試して急速融解のメカニズムを調査 し, 組織水点付近の温度通過速度が早いと被 害が顕著になることと細胞外凍結によって脱 水状態になった細胞が急速な融解により吸水 することが問題であると考察した。しかし， 酒井・吉田 ${ }^{13)}$ は，融解速度が+ $1^{\circ} \mathrm{C} \cdot \mathrm{min}^{-1}$ を 超えない限りトドマツの芽は有害な影響を受 けないこと, 朝日の直射による温度の上昇速 度が+0. $1^{\circ} \mathrm{C} \cdot \min ^{-1}$ であることを指摘し, 今 田・武藤 ${ }^{11}$ が6月に日中の太陽下で融解させた ことを理由に朝日説を否定している。一方, 吉田ら ${ }^{8)}$ は, 山の南東斜面に扔いて凍結後に 被覆して朝日を遮っても被害程度が緩和され なかったこと, 南東斜面に括ける芽の生育が 進んでいたこと，および南東斜面が最も低温 になりやすいことを明らかにして，朝日以外 の影響を指摘した。

本研究に打ける低温処理試験の結果では, 被害に大きな影響を及ぼした要因は生育ス テージ，処理温度および処理時間であった。 新芽が生育に伴い耐凍性を急速に消失する現 象は箩瀬》が指摘した結果と同様で, 特に試 験 I-2に扔いて被害芽率は 1 週間の調查間 隔で極端な増加を示した(表 2,3 )。本研究 では試験 $1-1,1-2,1-3$ とも, 東側 の新芽で被害芽率が高い傾向が認められたが (表 $1 ， 2 ， 3$ ), 一般に南北うね茶園では新 芽の生育は茶株面の東側で早い特性があるこ とから，耐凍性の低下が早かった可能性が示 唆された。

一方, 試験 $1-2$ の同一調查日に扔いて被 
害芽率の高低を比較すると, 処理温度の影響 が最も大きく僅か $1{ }^{\circ} \mathrm{C}$ 違いで損傷芽率と枯 死芽率が大きく異なった(表 $1 ， 2 ， 3 ， 4$ )。 しかし，融解方法による影響はほとんど認め られず, 淵之上 ${ }^{9)}$ と原田・中山 ${ }^{109}$ の研究結果と 異なっていた(表 $2 ， 3$ )。むしろ，急速融解 を組み合わせた一部の区では，低温遭遇時間 が短縮されたためか逆に損傷芽率が低下し た。本研究で急速融解による被害の拡大を再 現できなかった原因については，低温処理の 具体的方法や手順, フリーザー内の温度分布, 更に被害程度の判定法などの違いによる影響 が考えられるので, 個々の要因についての再 検討が必要であろう。しかし，日の出頃の茶 株面葉温の上昇速度は, 朝日が当たる東側肩 部で+0.13 $\mathrm{C} \cdot \mathrm{min}^{-1}$, 西側肩部で $+0.07^{\circ} \mathrm{C} \cdot$ min. ${ }^{-1}$ と僅かな差であったこと(図 5 ) と前述 したトドマツでの経過を考慮すると, 同樣な 試験を継続して自然界で起こり得ない処理に よって急速融解による被害拡大を再現できた としても，朝日説を証明する根拠にはならな いと考えられる。

凍霜害が局部的に発生する原因について は, 上述した茶芽の生理的要因とは別に耕地 微気象学の見地からの検討も必要である。本 研究で茶株面の葉温分布を調查した結果, 高 橋ら ${ }^{6)}$ が指摘したように低温時における主風 向の反対側である茶株面の東側が低温になり やすかった(図 3,4 , 写真 $3 \sim 10$ )。特に東,
西肩部の葉温はほとんどの場合で $1{ }^{\circ} \mathrm{C}$ 以上の 差があり，顕著な場合は $2^{\circ} \mathrm{C}$ 以上になった。 これらの差は試験 $1-2,1-3$ の低温処理 において茶芽の生死を分けた水準差以上の違 いであり，たとえ東西間における茶芽の耐凍 性が同等であっても，被害芽率が大きく異な る可能性が伺えた。

傾斜に対して等高線に沿って植えられた弧 状樹形の茶園では，茶株面の山側よりも谷側 で新芽の生育が遅れたり，凍霜害を受けやす い特性がある。この現象は, 谷方向へ流れる 風の反対側である茶株面の谷側で温度低下が 著しいことが原因と説明されており ${ }^{5,19,24)}$, 朝 日の方向に起因しない。このため，これと同 様な現象である南北うねの平坦地茶園におい て茶株面の東側で凍霜害が発生しやすい原因 についても，朝日の方向を考慮しなくとも茶 株面の葉温差のみで説明が可能と考学られ る。

このように弧状樹形茶園で風向の反対側で 茶株面葉温が低下しやすい現象は，遮蔽物の 風下で涷霜害が集中しやすい現象と類似して いる。例えば, 三原ら 22 や静岡県茶業試験場 2 は, 防風林や防風垣の風下で凍霜害の被害が 䫓著であることを, 早川ら ${ }^{21}$ は, 風があるとき は高速道路の風下側で冷却されやすいことを 指摘している。凍霜害は中山間部の谷底や塞 地での発生が多く，山の山頂に近いほど発生 が少ないことが普遍的な現象として指摘され

Warmer wind than leaf temperature blows against the west side of the arc-shaped canopy surface.

風が当たる部分は，葉温が気温近くまで上昇する。

Leaf temperature rise to wind temperature

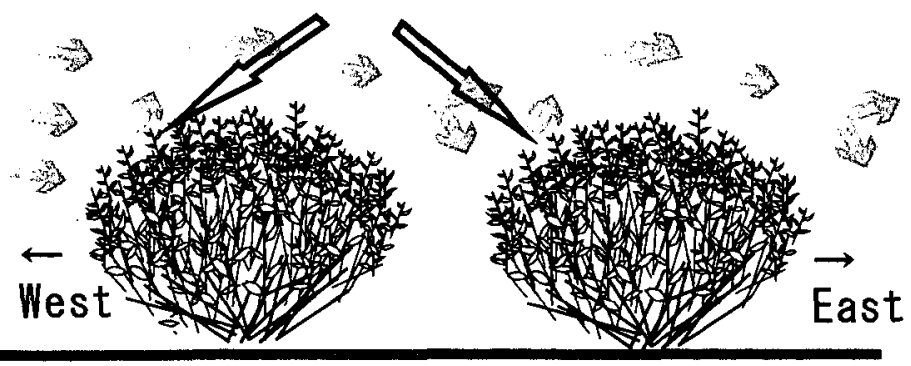

図 6 西風が茶株面の葉温に及ぼす影響

Fig. 6 Influence of wind form the west on the leaf temperature of the arc-shaped caonpy surface. 
ている ${ }^{2,6,23)}$ が，この原因は冷気流の移流と停 滞が凍霜害を助長するものと説明されてい た6)。しかし，1979年に開催された農業気象学 会のシンポジウム「霜害と夜間の冷気流 $\rfloor^{201}$ に おいて，三原はたとえ「冷気流」であっても 放射冷却で極端に温度低下した植物体にとっ ては「温風」であることを指摘し，それまで の通説であった霜害冷気流説を否定した。三 原の説を本研究結果に当てはめると,「なぜ東 側が凍霜害を受けやすいのか」ではなく「な ぜ西側が凍霜害を受けにくいのか」という着 眼により，図 6 のように説明される。すなわ ち, 放射冷却で気温より冷え込んだ茶株面に 西風が当たることによって, 西側の葉温が上 昇する。この結果, 東側の葉温は相対的に西 側より低くなるので, 茶株面の東側が凍霜害 を受けやすくなると考えられる。

\section{5 摘 要}

南北方向に定植され, 弧状樹形に仕立てら れた茶園では, 凍霜害が茶株面の東側に集中 する特性がある。本研究では, 茶株面の東・ 西側における茶芽の耐凍性, 低温処理および 融解方法の違いが, 新芽の損傷芽率や枯死芽 率に及ぼす影響について，さらに，低温時に おける茶株面の葉温分布について調査した。 低温処理試験結果と茶株面葉温の観測結果を 照らし合わせて，その原因について検討した 結果,

1、莱芽の凍結による被害に最も大きな影響 を及ほした要因は生育ステージであり, 生 育が進むにつれて損傷芽率と枯死芽率が増 加した。一部で異なる結果も得られたが, 茶株面の東側における茶芽の耐凍性は, 総 じて西側よりも僅かに低い傾向が伺えた。

2 . 茶芽の損傷芽率と枯死芽率は, 処理温度 が低いほど，また処理時間が長いほど增加 した。特に僅か $1{ }^{\circ} \mathrm{C}$ 処理温度差によって 枯死芽率や損傷芽率が大きく異なった。

3.AMeDASの牧の原観測点に扔ける過去 の気像デー夕を集計すると, 春先の低温時 は西高東低の気圧配置が多く, 西からの微 風条件下がほとんどであった。
4.茶株面の葉温は風向の反対側で低下する 現象がみられた。すなわち，最も多い西風 の微風条件では, 茶株面の東側は西側より も低く推移し, 顕著な場合, 両者間で $2{ }^{\circ} \mathrm{C}$ 以上の差がみられた。

以上の結果より, 南北方向に定植された弧 状樹形の茶園において, 茶株面の東側が凍霜 害が集中しやすい現象は, 茶株面の東側が低 温になりやすいことが主因であるが，東側の 耐凍性が低いことも影響していると考えられ た。

\section{6 謝辞}

本研究を遂行するにあたり, 野菜・茶業試 験場茶栽培部の渡辺利通作業技術研究室長に は, 熱映像温度計の使用と解析方法に関して 指導して頂いた。記して謝意を表する。

\section{引用文 献}

1）静岡県農政部茶業農産課 (1998)：平成10 年静岡県茶業の現状. 静岡, 27-28.

2 ) 静岡県茶業試験場 (1979)：昭和54年の茶 の凍霜害に関する調查報告. 静岡茶試研 報, 10,1-83.

3 ）中野敬之・小林栄人（1993）：萌芽前の低 温遭遇が茶芽の生育に及ほす影響。日本 農業気象学会1993年度全国大会講演要 旨, 238-239.

4) 中野敬之・谷 博司 (1994)：チャ冬芽の 休眠，耐凍性の推移と萌芽期予測への利 用. 日作東海支部報，118，17-18.

5 ）鈴木康孝・小林栄人（1995）：傾斜地茶園 における畦の山側と谷側の一番茶の生育 差とその改善方法。静岡茶試研報, 19 , 9-19.

6) 高橋恒二・青野英也・田中静夫・媇瀬好 充・吉川 茂 (1961)：茶樹の凍霜害に関 する研究. 降霜時の微細気象と凍霜害の 応急的ならびに栽培的防止法の研究. 東 近農試研報, 茶業部, 8, 28-151.

7 ) 築瀬好充 (1975)：茶樹の器官による耐凍 性の差異とその時期的変化. 茶研報, No.42, 19-24. 
8）吉田静夫・酒井 昭・渡辺富夫（1968）： 植物の霜害に関する研究II.トドマツの 晚霜害におよほす朝日の影響. 低温科学, 生物編, 26, 51-60.

9 ）淵之上弘子(1966)：営利栽培北限地带に おける茶樹の生育生理に関する研究。第 6 報 新芽の低温害とその後の生育にお よ浔す影響。日作紀, 34別, 515-516.

10）原田重雄・中山 仰 (1961)：凍結・融解 の速度と寒害発生との関係について. 茶 研報, No.18, 11-15。

11）今田敬一・武藤憲由（1958）：北海道主要 造林樹種の凍害に関する研究(II). 凍害 と朝日の影響. 北大演習林研究報告, 19 , 61-78.

12）酒井 昭·吉田静夫（1967）：植物の霜害 に関する研究 I . 霜害に抢よほす融解速 度の影響. 低温科学, 生物編, 25, 59-70.

13）吉田静夫・酒井 昭 (1967)：植物の霜害 に関する研究 I . 急速融解の害. 低温科 学, 生物編, $25,71-79$.

14）吉田静夫・酒井 昭 (1968）：植物の霜害 に関する研究II. 凍結状態での温度変動 に伴う氷の量の変化. 低温科学, 生物編, $26,23-31$.

15）羽生寿朗・松岡延浩 - 今 久 （1986）：作物の霜害と環境条件. 第 2 報 ダイズ苗葉面の乾湿が凍結温度に及ほす 影響. 農業気象, 41，331-335.

16）岡野通明・羽生寿郎・中山敬一・今 久
（1989）：ダイズ苗葉の凍結温度への葉 面露量の影響. 農業気象, 44, 275-280。

17）田沢 博 (1976)：作物霜害の機構につい ての提言. 農業気象, 32, 145-147.

18）山中捷一郎 - 羽生寿郎 - 西山 司 -中山 敬一(1982)：作物の霜害と環境条件。第 1 報ダイズ苗の霜害と凍結温度との関 係。農業気象，38，23-28.

19）青野英也 - 築瀬好充 - 田中静夫 - 野原定 夫・成瀬 弘・丹羽千秋 (1981)：階段畑 茶園における凍霜害発生とその気象特 性. 農気東海支部報, 38，29-32。

20）羽生寿朗(1979）：昭和54年度全国大会シ ンポジウム「霜害と夜間の気流」要旨. 農業気象, 35, 103-111.

21）早川誠而 - 谷 宏・顧 衛・鈴木義則 · 元田雄四郎 (1992)：夜間の接地気層の冷 却について。(1)観測で得られた夜間の冷 却に及沽す地形の影響. 山口大農学報, 40, 1-12.

22）三原義秋・鶴田浩一・根本 修 (1977)： 防風施設によって助長される霜害. 農業 気象, 33, 67-74.

23）鈴木義則・佐藤正一・川尻佳合（1982）： 暖地の凍霜害・寒害と地形気象。(1)宇部 小野茶園に颃ける最低気温分布。農業気 象, 37, 289-295.

24）高市益行・米谷 力（1993）: 冬季の成木 茶園における温度分布と樹体の凍結・融 解。農業気象, 49, 81-90. 


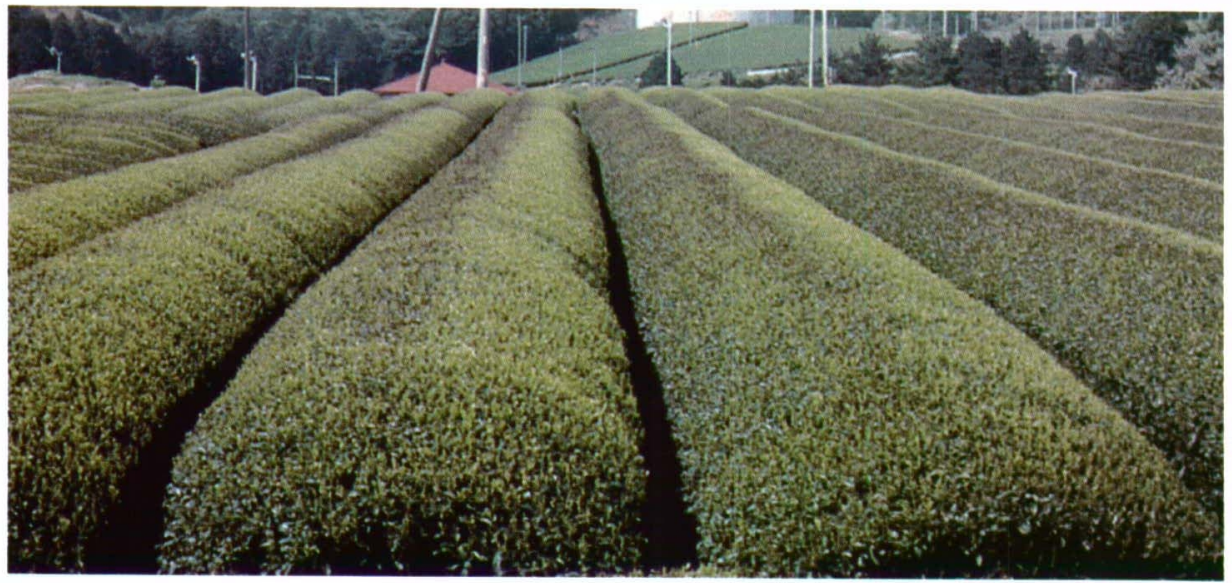

写真 1 茶株面の片側のみに発生した凍霜害（静岡県菊川町, 1993年 4 月, 手前が北) Plate. 1 Frost injuries occurred partially on arc-shaped canopy surface. 1) Phtographes at Kikugawa, Shizuoka in April, 1993. Left side means East.
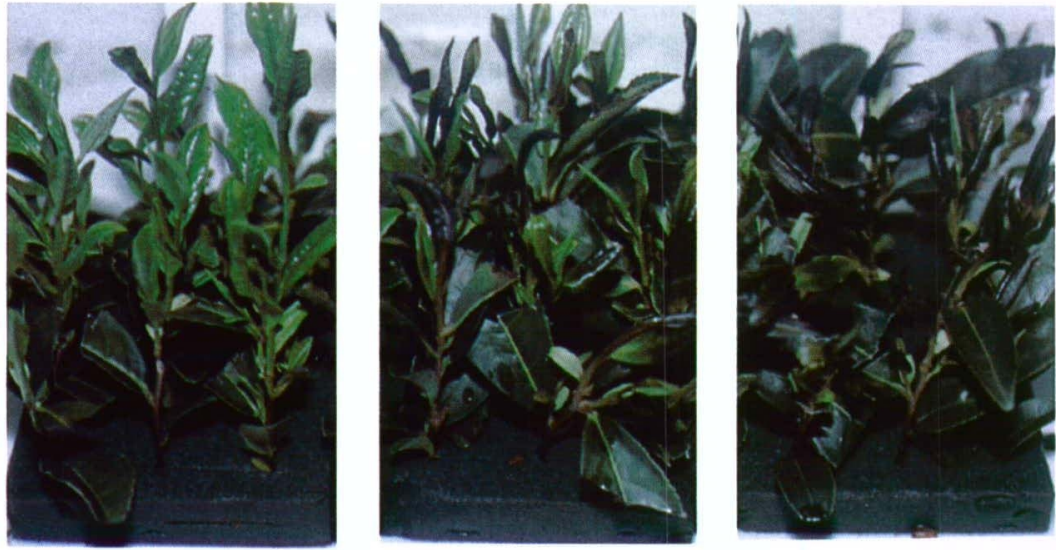

写真 $2-2{ }^{\circ} \mathrm{C} て ゙ 0$ (左), 2 (中), 4 時間（右）処理した後の新芽

Plate. 2 A scne of new shoots growth after freezing operation on Apr. 15 in 1998.

1) Left, center and right shoots showed 0,2 and 4 hrs. treatment at $-2^{\circ} \mathrm{C}$, respectively.

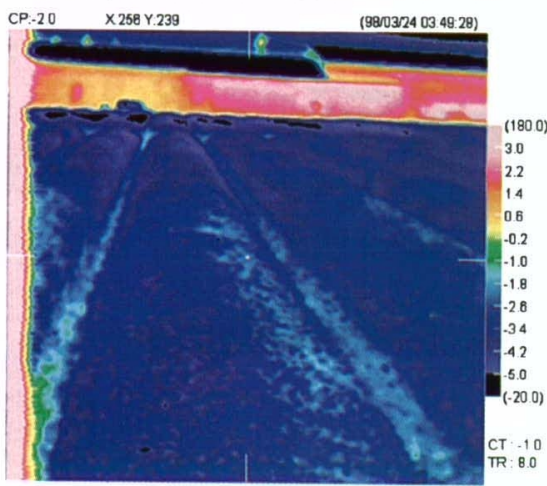

Plate 3 3:49AM

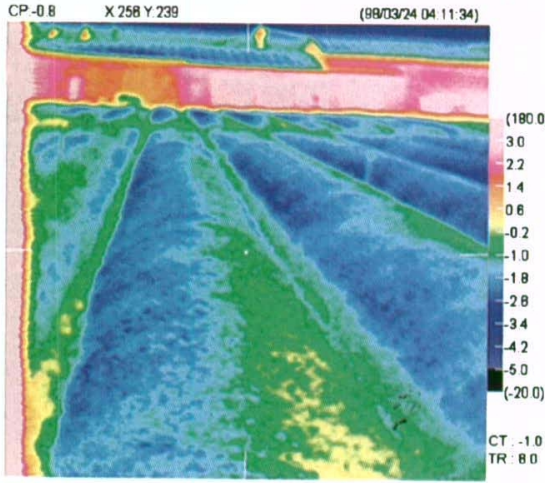

Plate 4 4:11AM

写真 3-4 熱映像温度で撮影した茶株面温度（その 1)

写真は1998年 3 月24日に収録した熱画像で, 左が東側を示す

In plate. 3-4 left and night side of each platc mean and west side, respectively. 


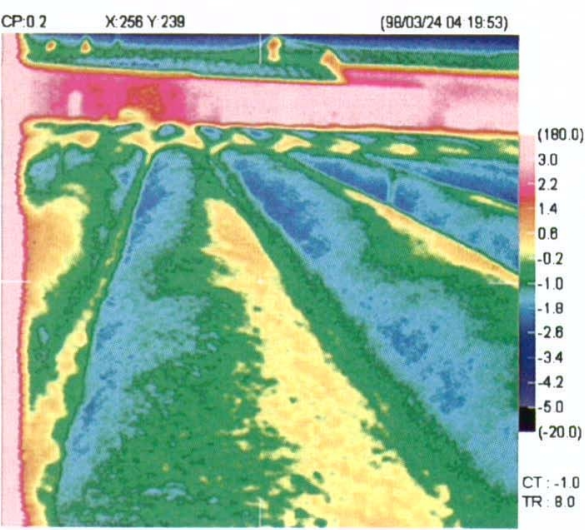

Plate 5 4:19AM

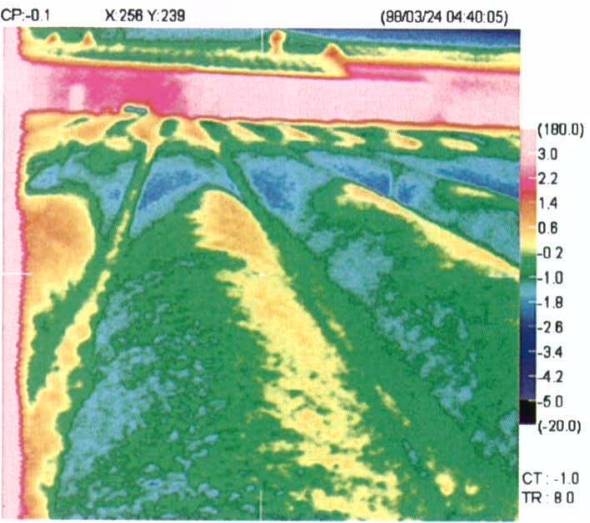

Plate $7 \quad$ 4:40AM

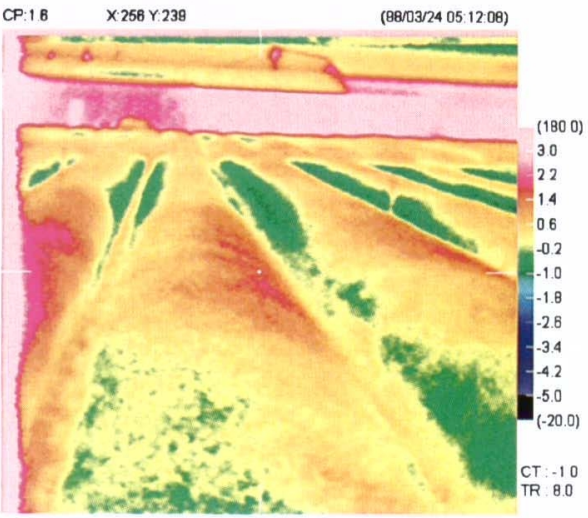

Plate 9 5:12AM

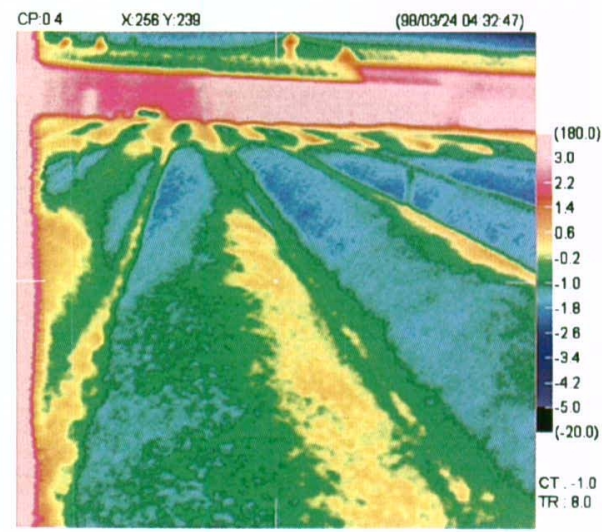

Plate $6 \quad 4: 32 \mathrm{AM}$

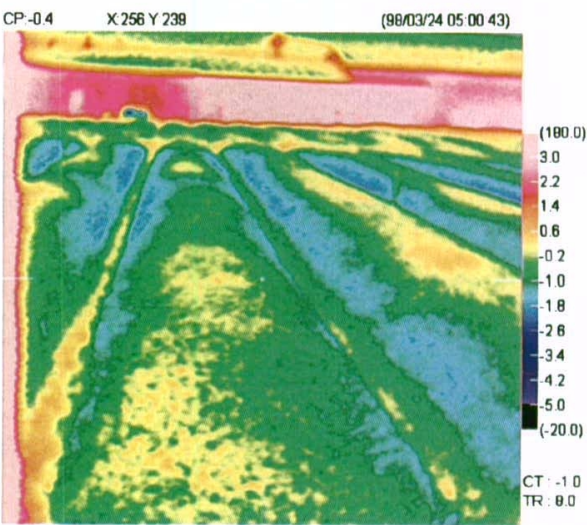

Plate $8 \quad 5: 00 \mathrm{AM}$

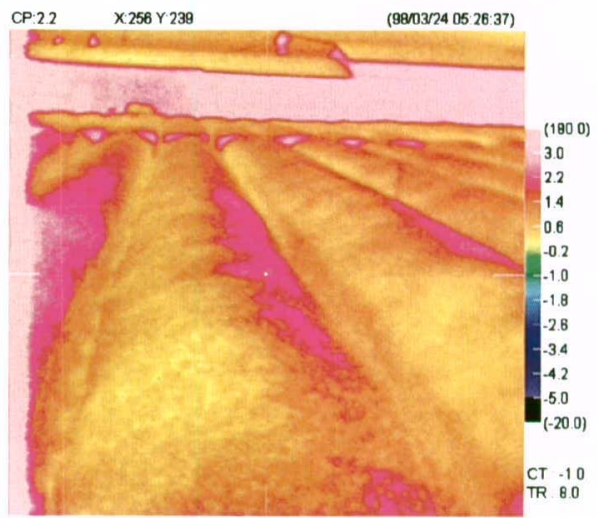

Plate $10 \quad 5: 26 \mathrm{AM}$

写真 4-10 熱映像温度で撮影した茶株面温度（その2）

写真は1998年 3 月24日に収録した熱画像で，左が東側を示す

In plate. 3-10 left and night side of each platc mean east and west side, respectively. 